\title{
REALITAS PENDIDIKAN AGAMA KHONGHUCU PADA TINGKAT SD DI KOTA PEKALONGAN JAWA TENGAH
}

\section{The Reality Of Confucianism Education for Pupils At The Elementary School Level in Pekalongan, Central Java}

\author{
A.M. Wibowo \\ Balai Penelitian dan Pengembangan Agama Semarang \\ Jl Untung Suropati kav 70 Bambankerep Ngaliyan Semarang Jawa Tengah \\ Email: denmasaam@yahoo.com
}

Naskah diterima tanggal 8 Mei 2014. Naskah direvisi tanggal 27 Juli 2014. Naskah disetujui tanggal 4 Agustus 2014

\begin{abstract}
Abstrak
Penelitian ini berusaha menemukan pola-pola proses pendidikan Agama Khonghucu bagi peserta didik sekolah dasar di Kota Pekalongan Jawa Tengah. Proses pendidikan yang dimaksud meliputi kurikulum pendidikan agama Khonghucu, kompetensi guru, proses pembelajaran, serta hambatan-hambatan pelaksanaan pendidikan agama Khonghucu di sekolah dasar. Dengan menggunakan pendekatan kualitatif penelitian ini berhasil menemukan 4 pola pelaksanaan pendidikan agama Khonghucu pada jenjang sekolah dasar. Pertama, pendidikan agama Khonghucu telah dilaksanakan pada dua sekolah dasar yaitu SDN Sampangan 02 dan SD Satyawiguna. Kedua, secara kualifikasi akademik dan standar kompetensi guru pendidikan agama Khonghucu belum mengacu dengan dipersyaratkan pemerintah dalam permendiknas No 16 tahun 2007 tentang kompetensi guru. Ketiga, kurikulum pendidikan agama Khonghucu yang dilaksanakan pada sekolah dasar di Pekalongan menggunakan kurikulum yang disusun oleh Majelis Tinggi Agama Khonghucu Indonesia (MATAKIN) dan tidak mengacu KTSP. Keempat, ditemukan enam faktor penghambat dalam pelaksanaan pendidikan agama Khonghucu pada tingkat sekolah dasar yaitu kualifikasi guru, perangkat pembelajaran yang tidak memadahi, proses pembalajaran yang monoton, ketidakmampuan guru pendidikan agama Khonghucu untuk bergaul dan sharing pendapat dengan pimpinan dan teman sejawat, monitoring pimpinan sekolah dan Majelis agama Khonghucu (MAKIN) yang belum maksimal, serta ketiadaan buku pelajaran bagi siswa Khonghucu.
\end{abstract}

Kata kunci: pola, pelaksanaan, sekolah dasar, pendidikan agama Khonghucu, hambatan.

\begin{abstract}
This research tries to find the process of Confucianism education for the pupils of the elementary school in Pekalongan Central Java. Educational process includes education curriculum of Confucianism, teacher competence, the learning process of Confucianism education and educational barriers to the implementation of Confucianism in the elementary school. By using this qualitative research approach successfully found four pattern of Confucianism education implementations in the elementary school level. The first, Confucianism education in the elementary school has been completely implemented in two schools were SDN Sampangan 02 and SD Satyawiguna. The second, academic qualifications and competence standard teacher of confucianism education has not been referring to the government as required under Decree No. 16 of 2007 concerning the academic competence of teacher. The third, curriculum of Confucianism education implemented in the elementary school in Pekalongan, Central Java using the curriculum developed by the Supreme Council for Confucian Religion in Indonesia (MATAKIN) and does not refer to KTSP. The fourth, there are six factors inhibiting for the implementation of Confucianism education found in elementary school are; qualification teachers, the learning does not support, monotonous learning process without innovation of teaching method, inability teacher to get along and to share opinions with the leaders and peers, the Council for Confucian Religion in Indonesia (MAKIN) and headmaster monitoring have not been maximized, and there is not the lack of textbooks for confusion students.
\end{abstract}

Keywords: pattern, implementation, elementary school, Confucianism education, barriers. 


\section{PENDAHULUAN}

$\mathrm{S}$ elama tidak kurang dari 20 tahun umat Khonghucu di Indonesia sempat hidup dalam tekanan dan pengekangan sebagai akibat tindakan diskriminatif terhadap pemeluknya. Namun patut disyukuri, pengakuan hak asasi manusia pada era reformasi mulai membaik.

Kebebasan beragama umat Khonghucu ini semakin jelas dengan keluarnya Peraturan Pemerintah RI Nomor 55 Tahun 2007 tentang Pendidikan Agama dan Pendidikan Keagamaan. PP tersebut menyebutkan bahwa perihal pendidikan agama Khonghucu dapat dilaksanakan pada jalur sekolah formal, non-formal, dan informal sebagaimana diatur dalam Pasal 45 ayat 3 yang berbunyi "Pengelolaan satuan pendidikan keagamaan Khonghucu dilakukan oleh pemerintah, pemerintah daerah, dan atau masyarakat".

Namun fakta masih menunjukan bahwa pelaksanaan pendidikan agama Khonghucu di Indonesia masih problematis. Meski payung hukum tentang pelaksanaan pendidikan agama Khonghucu bagi pemeluknya telah lahir yaitu Undang-Undang (UU) Nomor 5 Tahun 1969, Penetapan Presiden Nomor 1.Pn.Ps. Tahun 1965, UU Nomor 1 Tahun 1974 dan Peraturan Pemerintah Nomor 55 Tahun 2007, namun pada dataran praktik di lapangan pelaksanaan pendidikan agama Khonghucu ini masih terkesan setengah-setengah.

Meski keberadaan agama Khonghucu telah diakui pemerintah, namun hak-hak sipil para penganutnya belum sepenuhnya terpenuhi khsusunya dalam bidang pendidikan agama di sekolah. Selain itu juga masih terdapat salah persepsi di kalangan aparat pemerintah daerah tentang agama Khonghucu, sumber daya manusia di internal agama ini pun masih sangat minim.

Kurang maksimalnya pelaksanaan pendidikan agama Khonghucu bagi pemeluknya dimungkinkan karena dua faktor yaitu internal dan eksternal. Faktor eksternal disebabkan karena belum adanya perwakilan agama Khonghucu di Kantor Kementrian Agama baik di tingkat propinsi dan kabupaten kota seperti Bimas Islam, Kristen, Hindu dan Buddha sehingga kebijakan-kebijakan yang menyangkut pendidikan agama Khonghucu tidak terwakili. Sedangkan faktor internal adalah komponen pendidikan yang belum tersusun secara maksimal. Komponen pendidikan yang dimaksud meliputi penyusunan kurikulum, silabus, serta rencana pelaksanaan pembelajaran. Selain hal tersebut faktor sumber daya manusia berupa guru pendidikan agama yang kurang berkompeten turut mempengaruhi kurang maksimalnya pelaksanaan pendikakan agama Khonghucu di sekolah dasar.

Arnis Rachmadani(2009) dalam Penelitiannya yang berjudul Pembinaan Kehidupan Beragama Pada Masyarakat Tionghoa Yang Beragama Konghucu di Kota Malang Jawa Timur menemukan Bentuk-bentuk pembinaan keagamaan dan pemberdayaan warga Tionghoa beragama Khonghucu di Kota Malang Jawa Timur. Pembinaan dan pemberdayaan keagamaan Khonghucu dilakukan dalam bentuk khotbah, pemberian materi pelajaran, dan penerbitan. Sedangkan dalam bentuk pemberdayaan melalui proses pendidikan di sekolah belum dilakukan. Oleh karena itu penelitian tentang Pelaksanaan pendidikan Agama bagi peserta didik penganut Khonghucu sangat berbeda dengan apa yang dilakukan oleh Arnis Rachmadani.

Alasan dipilihnya jenjang pendidikan sekolah dasar dikarenakan pada usia-usia sekolah tersebut pendidikan agama sangat penting sebagai pondasi mental agama anak kelak ketika dewasa. Di mana pada anak usia SD perkembangan intelektual, perkembangan bahasa, perkembangan sosial, perkembangan emosi, perkembangan moral, perkembangan motorik, dan perkembangan keagamaan, mulai tumbuh (Hurlock, 1978: 117).

Tujuan pendidikan sebagaimana diungkapkan oleh Bloom adalah untuk menumbuh dan mengembangakan kecerdasan kognitif, affektif dan psikomotorik (Bloom, 1974). Kecerdasan kognitif berkenaan dengan kemampuan individual mengenal dunia sekitarnya yang meliputi perkembangan intelektual atau mental. Kecerdasan Afektif mengenai perkembangan sikap, perasaan, nilai-nilai yang sering disebut perkembangan emosional dan moral. Kecerdasan psikomotorik adalah kecerdasan yang menyangkut perkembangan keterampilan yang mengandung unsur motoris. Oleh kerena itu, untuk mencapai tujuan pendidikan tersebut di atas secara maksimal diperlukan sistem pendidikan yang benar-benar koheren dan tepat.

Terkait dengan agama Khonghucu, tujuan pendidikan agama Khonghucu (Ru Jiao) merupakan usaha sadar dan terencana untuk membantu peserta didik mengembangkan dirinya berupaya menjadi manusia berbudi luhur (Jun $\mathrm{Zi}$ ) yang dapat mengimani dan mengamalkan ajaran Agama Khonghucu agar selalu hidup di dalam cinta kasih, 
menjunjung tinggi kebenaran, keadilan, kewajiban, berlaku susila, bijaksana sehingga dapat dipercaya, yaitu satya kepada Tian atau Tuhan Yang Maha Esa beserta FirmanNya, dan tepa selira kepada sesama manusia (PP No 55 Tahun 2007).

Inti pendidikan agama sejujurnya adalah penanaman iman ke dalam jiwa anak didik. Pendidikan agama, dalam arti pendidikan dasar adalah pendidikan moral. Sebab Pendidikan Agama merupakan usaha bimbingan dan asuhan terhadap anak didik agar nantinya setelah selesai dari pendidikannya dapat memahami apa yang terkandung dalam ajaran agama secara keseluruhan, mengamalkan makna dan maksud serta tujuan, yang akhirnya dapat mengamalkan serta menjadikan agama sebagai pandangan hidupnya yang akhirnya dapat mendatangkan keselamatan di dunia dan akhirat kelak (Darajat, 2011: 88).

Permasalahan dalam artikel ini adalah tentang bagaimana proses pelaksanaan pendidikan agama Khonghucu peserta didik penganut Khonghucu pada sekolah dasar di Kota Pekalongan, Jawa Tengah. Permasalahan tersebut kemudian difokuskan pada 4 pertanyaan seperti (1) implementasi pendidikan agama Khonghucu bagi peserta didik di sekolah dasar, (2) kompetensi guru pendidikan Agama Khonghucu pada jenjang pendidikan sekolah dasar, (3) kurikulum yang digunakan dalam implementasi pendidikan agama Khonghucu, dan (4) faktor penghambat proses pelaksanaan pendidikan agama Khonghucu bagi peserta didik pada tingkat sekolah dasar di Kota Pekalongan. Penelitian ini diharapkan akan dapat menjadi refleksi tentang pelaksanaan pendidikan agama Khonghucu di propinsi Jawa Tengah bahkan di Indonesia.

Sedangkan tujuan penelitian ini adalah untuk mendeskripsikan pelaksanaan Pendidikan Agama Khonghucu bagi peserta didik pada sekolah jenjang pendidikan tingkat dasar di Kota Pekalongan, Jawa Tengah. Tujuan tersebut meliputi deskripsi tentang implementasi, kompetensi guru, kurikulum, serta faktor penghambat dan pendukung, pelaksanaan pendidikan Agama Khonghucu pada jenjang pendidikan tingkat sekolah dasar di Kota Pekalongan.

\section{METODE PENELITIAN}

Penelitian ini menggunakan pendekatan kualitatif, namun demikian untuk lebih menguatkan temuan dan pembahasan penelitian ini membutuhkan teknik kuantitatif (mixed method) (Brannen, 1992). Teknik kuantitatif dibutuhkan terkait dengan pembagian kuesioner untuk mengukur kompetensi guru, namun teknik kuantitaif hanyalah sebagi pendukung semata sebab analisis yang digunakan dalam penelitian ini adalah analisis kualitatif.

Metode pengumpulan data yang dilakukan dalam penelitian ini meliputi wawancara, observasi, dokumentasi, kuesioner. Kuesioner digunakan sebagai alat alat bantu untuk menggali standar kompetensi guru Pendidikan Agama Khonghucu pada tingkat Sekolah Dasar. Adapun instrumen yang dipergunakan dalam menyusun kuesioner adalah instrumen yang terdapat dalam lampiran Permendiknas No 16 Tahun 2007. Instrumen tersebut meliputi standar kompetensi guru pada bidang paedogogik, profesional, kepribadan dan sosial.

Analisis data dalam penelitian ini adalah analisi data interaksi (Staruss, 2007). Yaitu menghubungkan antara kategori dengan sub kategori untuk kemudian dicari pola-polanya. Teknik analisis data dalam penelitian ini menggunakan teknik analisis deskriptif. Teknik tersebut dilakukan dengan cara mereduksi data, memaparkan data dan melakukan kesimpulan (Sugiyono, 2008). Data yang ada dikumpulkan berdasarkan dengan tipologinya, kemudian reduksi data hingga diperoleh generalisasi mengenai gambaran tentang pelaksanaan pendidikan agama Khonghucu di Kota Pekalongan Jawa Tengah.

\section{PEMBAHASAN}

\section{Sejarah Pendidikan Agama Khonghucu di Indonesia}

Dalam catatan sejarah pendidikan di Indonesia, dapat dilihat lika-liku perjalan pendidikan Agama Khonghucu. Dimulai pada permulaan abad ke-20, dikarenakan kekecewaan terhadap pemerintahan Belanda orang Cina mendirikan perkumpulan Cina dan tersebar ke daerah-daerah seluruh Hindia Belanda. Sekitar tahun 1918 di Surakarta berdiri lembaga agama Khonghucu yang disebut "Khong Kauw Hwee" yang kemudian mendirikan lembaga pendidikan di bawah yayasan Khong Kau Hwee yang berafiliasi pada agama Khonghucu (Hadikusuma, 1993: 257).

Rentang Tahun 1900 hingga 1967 tercatat peran tokoh agama Khonghucu dalam membangun lembaga pendidikan swasta pertama yaitu Tiong Hwa Hwee Kwan atauTHHK (Bing, 2010) 
(Wikipedia.com). Pada era ini pendidikan agama Khonghucu terus berkembang dan dilaksanakan secara intensif oleh institusi yang disebut Shu Yan. Sekolah-sekolah dari jenjang sekolah dasar, menengah hingga perguruan tinggi terdapat kurikulum tengang pendidikan agama Khonghucu.

Pendidikan agama bagi segenap murid beragama Khonghucu juga sudah dilaksanakan lebih intensif semenjak 1967 di wajibkan di sekolah-sekolah di seluruh tanah air Indonesia. Dengan demikian dari sekolah dasar, menengah dan perguruan tinggi diadakan pula kurikulum pengajaran agama.

Berakhirnya era orde lama dan mulai berkuasanya orde baru telah berimbas pada kebijakan pemerintah tentang pendidikan Agama Khonghucu. Yaitu dengan dikeluarkannya dan diberlakukannya Instruksi Presiden No. 14 tahun 1967 dan diperkuat dengan Surat Edaran (SE) Menteri Dalam Negeri No. 477/74054/ BA.012/4683/95 tanggal 18 November 1978 yang isinya antara lain menyatakan bahwa agama yang diakui pemerintah adalah Islam, Kristen, Katolik, Hindu dan Budha maka secara perlahan-lahan pendidikan agama Khonghucu telah dihapus dari kurikulum pendidikan nasional.

Ketiga berakhirnya orde pemerintahan Soeharto selama 32 tahun berganti pada orde reformasi yang pada saat itu pemerintahan dipimpin oleh Presiden Abdurrahman Wahid kebijakan tentang Agama Khonghucu berubah kembali. Pemerintah mengeluarkan Keppres No. 6 tahun 2000 yaitu tentang pencabutan Inpres No. 14 tahun 1967 yang berimbas diakuinya kembali Khonghucu sebagai salah satu dari 6 agama yang diakui oleh pemerintah. Dengan demikian Pemerintah telah menegaskan kembali hak-hak umat Khonghucu, termasuk di dalamnya memasukkan pendidikan agama Khonghucu dalam kurikulum nasional.

Pada masa pemerintahan Susilo Bambang Yudhoyono pemerintah kembali menegaskan hakhak yang berkait dengan agama Khonghucu. Hal itu dituangkan dalam Peraturan Pemerintah (PP) Nomor 55 Tahun 2007 tentang Pendidikan Agama dan Pendidikan Keagamaan. Di mana pada bagian Keenam peraturan pemerintah tersebut mengatur tentang Pendidikan Keagamaan Khonghucu yaitu pasal Pasal 45 pasal 1 menyebutkan Pendidikan Keagamaan Khonghucu diselenggarakan oleh masyarakat pada jalur pendidikan formal, nonformal, dan informal. Pasal 2 Pendidikan Keagamaan Khonghucu berbentuk program
Sekolah Minggu, Diskusi Pendalaman Kitab Suci, Pendidikan Guru dan Rohaniwan Agama Khonghucu, atau bentuk lain yang sejenis. Dan pasal 3 pengelolaan satuan Pendidikan Keagamaan Khonghucu dilakukan oleh pemerintah, pemerintah daerah, dan atau masyarakat.

\section{Umat Khonghucu di Kota Pekalongan}

Hingga pengumpulan data penelitian ini berakhir belum diketahui secara pasti berapa jumlah umat pemeluk Khonghucu di kota Pekalongan. Namun berdasarkan hasil wawancara dengan beberapa tokoh Majelis Agama Khonghucu Indonesia Pekalongan diperoleh data bahwa umat Khonghucu di Pekalongan ada sekitar 350-an orang, namun yang aktif pada kebaktian di lithang (tempat ibadah umat Khonghucu) hanya sekitar 50 sampai 75 orang.

Secara geografis SD Negeri Sampangan 02 dan SD Satyawiguna terletak berdampingan yaitu di Jalan Salak No 30 dan 31 Pekalongan Utara Kota Pekalongan. Dua sekolah tersebut terletak di daerah pecinan di daerah pasar Banjar Kota Pekalongan. Dalam radius 200 meter dari dua sekolah dasar tersebut terdapat berbagai tempat ibadah seperti vihara, lithang, gereja, dan klenteng untuk umat Tridarma.

Dalam pelaksanaan pendidikannya SDN Sampangan 02 Pekalongan memiliki beberapa visi yang terangkum dalam sebuah cita-cita sekolah. Visi SD Sampangan 02 yaitu "Membentuk generasi yang bertakwa, unggul dalam prestasi berakhlak mulia serta santun dalam bertingkah laku". Untuk mewujudkan visi tersebut maka sekolah mencoba mewujudkannya ke dalam misi sekolah. Misi Sekolah Dasar Sampangan 02 ada 7 buah yaitu; 1) membekali pendidikan agama pada siswa dengan kepercayaannya, 2) membekali ilmu pengetahuan pada siswa sesuai dengan kurikulum yang berlaku, 3) memberi tugas penelitian sederhana tentang sosial kemasyarakatan di lingkungan siswa, 4) membekali latihan kedisiplinan melalui upacara sekolah, 5) mengikuti kegiatan-kegiatan lomba pendidikan, 6) memberikan kegiatan kepramukaan agar siswa dapat berlaku jujur terampil dan dapat dipercaya, 7) memberikan kegiatan ekstrakurikuler yang bersifat akademik dan non akademik.

Semua visi dan misi tersebut tidak lain bermuara pada satu tujuan sekolah yaitu untuk mewujudkan tujuan sekolah sebagai bagian dari tujuan pendidikan nasional yakni meningkatkan kecerdasan, pengetahuan, kepribadian, akhlak 
mulia, serta ketrampilan untuk hidup mandiri dan mengikuti pendidikan lebih lanjut.

Jumlah keseluruhan pendidik atau guru di SD N 02 Sampangan sebanyak 13 orang. Dilihat dari jabatannya tenaga pendidik tersebut di atas terdiri dari guru kelas, guru agama dan guru wiyata bakti. Guru kelas terdiri atas 6 orang, 4 orang guru agama, 3 orang guru wiyata bakti. Dilihat dari statusnya, tenaga pendidik yang mengajar di SDN Sampangan 02 dapat dibedakan menjadi tiga. Berstatus PNS berjumlah 9 orang guru, dan 3 orang adalah tenaga honorer (wiyata bakti), dan satu orang bantuan dari MAKIN Kota Pekalongan.

Guru agama yang mengajar di SD Negeri Sampangan 02 Pekalongan berjumlah 6 orang, yaitu guru agama Islam 2 orang, Katholik, Hindu, Buddha, Khonghucu masing masing 1 orang. Jika dilihat dari tingkat kesarjanaannya, SDN Sampangan 02 hanya memiliki satu orang guru agama yang berpendidikan S-1. Sedangkan 3 orang guru agama lainnya hanya berpendidikan terakhir D-II. Seorang lagi hanya lulusan SMA yaitu guru pendidikan agama Khonghucu.

Komponen Peserta Didik. Secara keseluruhan jumlah siswa yang menjadi peserta didik pada SD Negeri Sampangan 02 berjumlah 133 orang masing-masing terbagi dalam satu rombongan belajar. Berdasarkan agama jumlah peserta didik mayoritas adalah beragama Kristen yaitu 75 orang siswa, Islam, 25 siswa, Katolik 13 siswa, Buddha 15 orang siswa, Hindu 3 orang siswa dan Khonghucu 2 orang siswa.

Kurikulum. Kurikulum SD memuat 8 mata pelajaran, muatan lokal, dan pengembangan diri. Pembelajaran pada Kelas I s.d. III dilaksanakan melalui pendekatan tematik, sedangkan pada Kelas IV s.d. VI dilaksanakan melalui pendekatan mata pelajaran. Jam pembelajaran untuk setiap mata pelajaran dialokasikan sebagaimana tertera dalam struktur kurikulum. Alokasi waktu satu jam pembelajaran adalah 35 menit. Pendidikan agama mempunyai porsi sebanyak 3 jam pelajaran selama satu minggu. Penentuan struktur kurikulum yang diterapkan di SDN Sampangan 02 ini sesuai dengan permendiknas nomor 22 tahun 2006.

Visi yang ditetapkan oleh SD Satyawiguna adalah "Mewujudkan anak Indonesia atau bangsa yang berbudi pekerti luhur, kreatif, mandiri, gemar belajar, disiplin dan berpijak pada budaya bangsa". Visi tersebut kemudian dijabarkan pada misi sekolah. Adapun misi sekolah adalah sebagai berikut; 1) menghasilkan anak didik yang berprestasi tinggi dan mampu bersaing melanjutkan pendidikan ke jenjang yang lebih tinggi, 2) melaksanakan pendidikan yang baik untuk anak didik sehingga menjadi insan yang memiliki budi pekerti luhur, kreatif, mandiri disiplin dan gemar belajar, 3) berorientasi pada pengembangan anak didik semangat belajar tanpa henti yang berlandaskan pada prinsip profesionalisme, 4) menjadi tempat untuk menumbuhkan budaya akademik dan budaya organisasi sehingga menjadi kebanggaan bagi civitas akademikanya.

Komponen Pendidik. Jumlah tenaga pendidik pada SD Satyawiguna semuanya berjumlah 22 orang. Dari ke-22 orang tersebut 9 orang merangkap menjadi guru SMP dan TK. Dari keseluruhan jumlah guru hanya 4 yang berstatus pegawai negeri sipil lainnya adalah Guru Tetap Yayasan, Guru Tidak Tetap dan Guru Honorer. Guru agama pada SD Satyawiguna berjumlah 5 orang yaitu masingmasing satu orang untuk guru mata pelajaran Islam, Kristen, Katolik, Buddha dan Khonghucu.

Komponen Siswa. Jumlah peserta didik yang bersekolah di SD Satyawiguna semuanya berjumlah 250 orang. Jumlah peserta didik tersebut dibagi ke dalam 9 kelas yaitu kelas I, II, III, masing-masing 2 rombongan belajar, dan Kelas IV, V, VI masingmasing satu rombongan belajar. Komposisi siswa berdasarkan agama adalah Kristen 151 orang siswa, Katolik 46 siswa, Buddha 32 siswa, Islam 20 siswa, dan satu orang siswa memeluk agama Khonghucu. Dengan demikian mayoritas peserta didik di SD satyawiguna memeluk agama Kristen diikuti Katolik, Buddha, Islam dan terakhir Khonghucu.

Kurikulum. Kurikulum yang berlaku di SD Satyawiguna KTSP. Struktur kurikulum SD meliputi substansi pembelajaran yang ditempuh dalam satu jenjang pendidikan selama enam tahun mulai Kelas I sampai dengan Kelas VI. Kurikulum SD memuat 8 mata pelajaran, muatan lokal, dan pengembangan diri. Pembelajaran pada Kelas I s.d. III dilaksanakan melalui pendekatan tematik, sedangkan pada Kelas IV s.d. VI dilaksanakan melalui pendekatan mata pelajaran. Pendidikan agama mempunyai porsi sebanyak 2 jam pelajaran selama satu minggu. Penentuan struktur kurikulum ini tidak sesuai sesuai dengan permendiknas nomor 22 tahun 2006.

\section{Realitas Pelaksanaan Pendidikan Agama Khonghucu di Sekolah Dasar}

Pelaksanaan pendidikan agama khonghucu di Kota Pekalongan berawal dari keprihatinan para orang tua peserta didik, Majelis Tinggi Agama 
Khonghucu (MATAKIN) Komisariat Daerah Jawa Tengah dan Majelis Agama Khonghucu (MAKIN) Kota Pekalongan. Mereka prihatin melihat anakanak mereka yang memeluk agama Khonghucu tidak mendapat pelayanan pendidikan agama di sekolahnya.

MATAKIN dan MAKIN kemudian melayangkan surat permohonan baik kepada Departemen Agama dan Dinas Pendidikan yang isinya adalah permohonan agar peserta didik yang beragama Khonghucu diberi kesempatan untuk mengenyam pendidikan agama yang dipeluknya. Pihak Depag (sekarang Kemenag) mengundang seluruh Kepala Sekolah untuk memfasilitasi untuk mencari titik temu pendidikan agama Khonghucu di sekolah. Terjadi diskusi pada seputar honor guru pendidikan agama Khonghucu yang akhirnya terjadi kesepakatan mengenai pembayaran honor guru yang dibayarkan melalui Majelis Agama Khonghucu Kota Pekalongan. Besarnya honor yang diterima guru adalah Rp. 300.000,00.

\section{Kurikulum Pendidikan Agama Khonghucu}

Kurikulum merupakan suatu rencana yang disusun untuk melancarkan proses berlajar mengajar di bawah bimbingan dan tanggungjawab sekolah atau lembaga pendidikan beserta staf pengajarnya. Kurikulum pendidikan agama Khonghucu yang dipergunakan guru pendidikan agama Khonghucu pada tingkat Sekolah dasar di Kota Pekalongan merupakan kurikulum yang disusun oleh MATAKIN. Kurikulum tersebut sedikit berbeda dengan apa yang terdapat dalam Permendiknas No 47 tahun 2008 tentang standar isi mata pelajaran Pendidikan Agama Khonghucu. Struktur kurikulum yang disusun oleh MATAKIN masih mempergunakan istilah GBPP (GarisGaris Besar Program Pengajaran) layaknya istilah kurukulum tahun1994. Namun jika dilihat isinya sudah menggunakan kata semester untuk jenjang program pendidikannya. Sedangkan permendiknas No 47 Tahun 2008 tidak lagi menggunakan istilah GBPP tetapi standar isi mata pelajaran Pendidikan Agama Khonghucu.

Struktur Kurikulum yang disusun MATAKIN berisi pendahuluan, fungsi, tujuan, ruang lingkup, bahan yang dibahas dalam Pendidikan Agama Khonghucu, serta rambu-rambu dalam melaksanakan GBPP. Sedangkan struktur kurikulum yang terdapat pada permendiknas No 47 tahun 2008 berisi latar belakang, tujuan, ruang lingkup, dan standar kompetensi dan kompetensi dasar untuk SD.

Berkenaan dengan kurikulum yang dipergunakan oleh guru pendidikan agama Khonghucu pada sekolah dasar di Kota Pekalongan, struktur GBPP pendidikan Agama Khonghucu berisi dua bab. Bab pertama adalah Pendahuluan yang berisi tentang pengertian pendidikan agama Khonghucu, fungsi Pendidikan Agama Khonghucu, tujuan, ruang lingkup dan rambu rambu Pendidikan Agama Khonghucu.

Pelaksanaan Kurikulum. Pelaskanaan kurikulum yang dimaksud dalam penelitian ini meliputi dua hal yaitu kebijakan sekolah dan pelaksanaan kurikulum oleh guru pendidikan agama Khonghucu. Pelaksanaan kurikulum pendidikan agama pada masing-masing sekolah berbeda-beda. Perbedaan tersebut terletak pada jumlah jam pelajaran pada yang disediakan pada masing-masing sekolah. Pada SD Negeri sampangan 02 Kota Pekalongan jumlah jam pelajaran untuk semua mata pelajaran pendidikan agama adalah 3 jam perminggu. Sedangkan pada SD Satyawiguna jumlah jam pelajaran untuk semua mata pendidikan agama hanya 2 jam perminggu. Alasan mengapa jam pelajaran pendidikan agama dikurangi oleh pihak sekolah adalah alasan kebijakan yayasan.

\section{Profil Guru Pendidikan Agama Khonghucu Sekolah Dasar}

Guru pendidikan agama Khonghucu pada tingkat sekolah dasar diampu oleh seorang perempuan berinisial YS seorang warga keturunan Tiong Hoa kelahiran Pekalongan 15 Juli 1985. Pada saat penelitian berlangsung ia mengajar mata pelajaran pendidikan agama Khonghucu di dua buah sekolah dasar yaitu SDN Sampangan 02 dan SD Satyawiguna Kota Pekalongan.

Pada awalnya YS merupakan penganut Katolik. Pendidikan terakhir YS adalah tamatan SMA Santo Bernadus Kota Pekalongan dan berhasil menamatkannya pada tahun 2003. Setamat SMA karena mengikuti ajakan orang tua YS berpindah agama dari Katolik menjadi Khonghucu.

Keaktifannya pada upacara kebaktian di lithang Khonghucu milik Majelis Agama Khonghucu serta usianya yang masih muda menjadikan Jiasong (sebutan Rohaniwan Khonghucu) Indang Wijaya menunjuknya menggantikan Jiasong Ong Giok Lan untuk mengajar pendidikan agama Khonghucu di sekolah dasar. 
Dalam hal pembayaran honor untuk guru pendidikan Agama Khonghucu, semuanya diserahkan oleh Majelis Agama Khonghucu Kota pekalongan karena sekolah tempat guru mengajar tidak menyediakan alokasi untuk guru pendidikan Agama Khonghucu. Adapun besarnya honor yang diberikan kepada guru-guru pendidikan agama Khonghucu baik pada tingkat SD maupun SMP adalah Rp. 300.000 perbulan. Honor tersebut tidak tergantung pada berapa sekolah yang diampu guru pendidikan Khonghucu tetapi satu paket.

\section{Proses Pembelajaran Pendidikan Agama Khonghucu}

Proses pembelajaran pendidikan Agama Khonghucu biasanya dilakukan diberbagaitempat di luar kelas seperti perpustakaan, ruang tamu sekolah, ruang tata usaha bahkan di ruang Kepala Sekolah. Pembelajaran pendidikan Agama Khonghucu yang dilaksanakan pada dua sekolah dilakukan dengan menggunakan model pembelajaran individual. Hal tersebut dikarenakan jumlah peserta didik pada setiap proses pembelajaran tak lebih dari 4 orang orang untuk satu sekolah.

Jadwal pembelajaran pendidikan agama Khonghucu di SDN Sampangan 02 berlangusung pada Selasa jam 07.30 WIB. dan Rabu jam 09.00 WIB. Sedangkan pada SD Satyawiguna jadwal pelajaran pendidikan Agama Khonghucu dilakukan pada Selasa pukul 08.50 WIB.

Secara umum proses pembelajaran dimulai dengan posisi duduk guru dan peserta didik berdampingan. Pelajaran dimulai dengan membaca doa pembuka dan doa peneguh iman. Setelah itu murid dan guru berdiri saling memberi hormat. Posisi tangan ketika melakukan hormat adalah tangan kiri menggenggam kearah dada posisi ibu jari berdiri berdampingan.

Setelah doa dan penghormatan dilakukan maka pelajaran inti dimulai. Dari observasi yang dilakukan pada dua buah sekolah guru pendidikan Agama Khonghucu memulai pelajaran dengan cara membuka beberapa buku yang di bawanya. Dari raut mukanya nampak guru pendidikan Agama Khonghucu terlihat canggung dan bingung materi apa yang harus diberikan. Hal tersebut dikarenakan guru pendidikan agama Khonghucu tidak menyusun Silabus dan RPP sehingga ia tidak memiliki pedoman untuk mengajar. Sedangkan untuk menyusun Silabi dan RPP guru merasa tidak sanggup karena tidak tahu ilmunya.
Pada saat mengajar guru selalu membacakan buku teks pelajaran kepada siswa tanpa memperhatikan kalau konsentrasi siswa terpecah kepada pelajaran lain yang tengah berlangsung di ruang perpustakaan. Buku-buku yang selalu menamani guru pendidikan agama Khonghucu pada tingkat sekolah dasar ini adalah sebagai berikut:1) Tanya Jawab Keimanan Konfusiani disusun oleh Xstjhie Tjay Ing, 2) Tata Agama dan Tata Upacara Agama Khonghucu, 3) Sari Genta Suci Konfusian diterbitkan MATAKIN, 3) Riwayat Hidup Nabi Khonghucu Oleh MATAKIN, dan 4) PanduanPengajaran Dasar Agama Khonghucu.

\section{Kompetensi Guru Pendidikan Agama Khonghucu}

Berdasarkan permendiknas No 16 Tahun 2007 kompetensi guru pendidikan Agama Khonghucu dapat diketahui dari dua hal yaitu kualifikasi akademik guru dan standar kompetensi guru agama.

Berdasarkan permendiknas No 16 Tahun 2007 kompetensi akademik seorang guru SD dan SMP harus memiliki kualifikasi pendidikan minimum diploma empat (D-IV) atau sarjana S-1 dalam bidang pendidikan SD/MI atau program studi sesuai yang diajarkannya. Hasil penelitian menunjukan secara kualifikasi akademik guru pendidikan agama Khonghucu pada tingkat sekolah dasar belum sesuai kualifikasi yang diharapkan. Guru pendidikan agama Khonghucu pada dua sekolah dasar tersebut hanya mengenyam pendidikan sampai dengan tingkat SMA saja dan tidak memiliki sertifikasi uji kesetaraan dari lembaga terkait. Kedua, pemahaman guru terhadap materi yang diajarkan dapat dikatakan belum maksimal dalam penguasaan materi, penguasaan metode pengajaran, pengelolaan kelas, dan penguasaan komunikasi antara guru dan peserta didik.

Standar kompetensi guru pendidikan agama Khonghucu pada sekolah dasar dapat dinilai dari empat hal yaitu kemampuan paedogogik, profesionalisme, kepribadiann dan kompetensi sosial (Permendiknas No 16 Tahun 2007). Hasil penelitian menunjukan ada dua hal yang harus dibenahi oleh guru pendidikan agama Khonghucu dalam rangka peningkatan kompetensi paedagogiknya sehingga bisa meningkat dengan nilai minimal baik. Dua hal tersebut adalah pertama, dalam hal kesungguhan dalam mempersiapkan pembelajaran.

Dari hasil wawancara dan telaah dokumentasi ditemukan bahwa guru pendidikan Agama 
Khonghucu terlihat kurang maksimal dalam mempersiapkan pembelajaran seperti belum dibuatnya silabus dan rencana pembelajaran pelajaran pendidikan Agama Khonghucu. Dalam pengelolaan kelas oleh guru pendidikan agama Khonghucu Guru nampak tidak dapat menguasai manajemen kelas.

Dalam pengelolaan kelas misalnya guru terlihat kurang maksimal dalam memanfaatkan ruang belajar yang ada. Idealnya guru memiliki keterampilan dalam mengelola kelas dikarenakan untuk menciptakan iklim yang kondusif. Dari hasil observasi diketahui bahwa ruang belajar pendidikan agama Khonghucu tidak berada di kelas namun memanfaatkan ruangan yang disediakan oleh sekolah seperti perpustakaan, ruang tamu dan bahkan ruang tata usaha.

Dicontohkan pembelajaran yang dilakukan di ruang perpustakaan yang bercampur dengan pembelajaran pendidikan Agama Buddha. Suara yang lemah dan kecil dari guru pendidikan Agama Khonghucu tidak mampu mengalahkan suara anak-anak yang gaduh dalam proses pembelajaran Agama Buddha sehingga siswa Khonghucu lebih terfokus dalam pelajaran pendidikan agama Buddha dibandingkan dengan pelajaran Agama Khonghucu yang dianutnya.

Secara kompetensi profesional hasilnya penelitian menunjukan terdapat beberapa hal yang harus diperbaiki agar secara profesional kemampuan guru pendidikan Agama Khonghucu berada dalam keadaan minimal baik. Beberapa hal tersebut adalah sebagai berikut. Pertama, keluasan wawasan keilmuan. Seperti diketahui, guru pendidikan Agama Khonghucu hanya memiliki kualifikasi akademik sampai dengan SMA saja. Hal tersebut akan berakibat dalam proses pembelajaran di kelas, seperti guru tidak mampu berkreasi dalam mencipatkan inovasi pembelajaran di dalam proses belajar mengajarnya. Akibat kualifikasi akademik yang belum memenuhi syarat tersebut berdampak pada monotonnya cara mengajar guru.

Guru pendidikan Agama Khonghucu tidak mengetahui macam-macam metode pembelajaran yang baik dalam pembelajaran secara individual. Penguasaan guru atas isu-isu mutahir dalam bidang yang diajarkan tidak pernah di asah. Guru pendidikan agama Khonghucu berdasaran hasil pengamatan dan wawancara terungkap tidak pernah sekalipun menggabungkan isu-isu terkini dengan materi yang diajarkan kepada siswanya. Yang selalu guru pendidikan Agama Khonghucu pergunakan dalam mengajar adalah buku-buku tentang agama Khonghucu yang diterbitkan oleh MATAKIN Pusat.

Secarakompetensikepribadian hasil penelitian menunjukan kepribadian guru pendidikan Agama Khonghucu masuk dalam kategori baik. Namun demikian kategori baik tersebut masih perlu diperbaiki sehingga ketegori tersebut menjadi sangat baik. Pertama, seorang guru yang berwibawa harus memiliki kelebihan dalam merealisasikan nilai spiritual, emosional, moral, sosial, dan intelektual dalam pribadinya serta memiliki kelebihan dalam pemahaman ilmu pengetahuan, teknologi, dan seni sesuai bidang yang dikembangkan. Kedua yang perlu diperbaiki dalam rangka memperbaiki kompetensi kepribadiannya adalah kemampuan mengendalikan diri dalam berbagai situasi dan kondisi. Dari hasil observasi di dalam kelas tampak guru kurang maksimal dalam usaha mengendalikan kelas ketika proses belajar mengajar tengah berlangsung. Guru hendaknya memberikan reaksi terhadap gangguan-gangguan yang menyebabkan peserta didik tidak konsentrasi dalam menerima pelajaran. Contoh gangguan-gangguan yang sering terjadi dalam proses pembelajaran di kelas adalah gangguan dari pelajaran lain yang tengah berlangsung dalam satu ruangan.

Secara kompetensi sosial guru agama pendidikan Khonghucu meliputi 5 aspek yaitu (1) kemampuan menyampaikan pendapat, (2) Kemampuan menerima kritik, saran dan pendapat orang lain, (3) mudah bergaul dikalangan sejawat karyawan dan siswa, (4) mudah bergaul dikalangan masyarakat, (5) toleransi terhadap keberagamaan di masyarakat. Secara umum hasil kuesioner pada bidang sosial rerata kompetensi sosial guru pendidikan berada dalam kategori baik. Namun secara khusus masih terdapat aspek-aspek dalam kompetensi sosial guru pendidikan Agama Khonghucu yang perlu diperbaiki agar kondisi kompetensi tersebut memperoleh nilai minimal baik dari pimpinan sekolah dan teman sejawat. Pertama, kemampuan menyampaikan pendapat, hasil pengumpulan data terungkap guru pendidikan agama adalah sosok yang pendiam, jarang bergaul dengan teman sejawat.

Sifat pendiam dan jarang bergaul dengan orang lain menyebabkan seseorang akan merasa tidak percaya diri dan tentunya canggung ketika hendak berbagi atau berdiskusi dengan sesama guru untuk memcahkan persoalan-persoalan terkait 
proses belajar. Diperlukan pembiasaan untuk berkomunikasi serta berdiskusi dengan sesama guru agar guru pendidikan Agama Khonghucu memperoleh dan mendapat masukan dari guruguru lain dalam rangka meningkatkan proses pembelajaran pendidikan agar lebih maskimal.

Mudah bergaul dengan kalangan sejawat, masyarakat merupakan hal yang sangat penting dilakukan oleh seorang guru. Kemauan untuk bergaul dikalangan teman sejawat, karyawan dan siswa harus ditumbuh kembangakan mengingat selama ini guru pendidikan Agama Khonghucu pada sekolah dasar dinilai oleh sebagian orang masih sulit untuk berkomunikasi, bergaul dengan sesama guru dan karyawan bahkan siswa. Dengan menjalin komunikasi dan bergaul dengan komponen pendidikan tersebut maka diharapkan akan mengurai benang kusut kesulitan kesulitan yang dihadapi oleh guru agama karena mau berbagi.

\section{Faktor Penghambat Pendidikan Agama Khonghucu}

Penelitian ini menemukan enam faktor penghambat yang mengganggu keberhasilan pelaksanaan pendidikan Agama Khonghucu di tingkat sekolah dasar. Faktor-faktor penghambat adalah sebagai berikut:

Pertama, secara kualifikasi guru pendidikan Agama Khonghucu yang belum memenuhi apa yang diharapkan oleh Permendiknas baik secara akademik dan maupun uji kesetaraan guru. Kedua, belum tersusunnya perangkat pembelajaran seperti silabus dan RPP yang menyebabkan proses pendidikan Agama Khonghucu tidak berjalan sesuai yang diharapkan. Ketiga, guru tidak mampu menciptakan inovasi pembelajaran yang aktifkreatif, dan menyenangkan sehingga siswa tertarik pada pelajaran pendidikan Agama Khonghucu. Keempat, dalam hal pergaulan guru pendidikan Agama Khonghucu guru jarang bergaul atau sharing kepada guru yang lain, kelima, tidak tersedianya buku-buku referensi bagi peserta didik di perpustakaan sekolah. Ketiadaan referansi atau literatur ini menyebabkan peserta tergantung pada buku-buku yang dibawa oleh guru pendidikan Agama Khonghucu. Keenam, Monitoring dari Pimpinan Sekolah dan Majelis Khonghucu Indonesia yang belum maksimal. Monitoring diperlukan dalam rangka melakukan evaluasi terhadap kinerja guru pendidikan Agama Khonghucu agar lebih baik.

\section{PENUTUP}

Pendidikan agama merupakan bagian terpenting dan harus diperhatikan secara sungguhsungguh dalam pembentukan karakter keagamaan peserta didik. Diperlukan kesungguhan dari seluruh komponen pendidikan untuk mewujudkan pendidikan agama yang berkualitas. Penelitian ini menghasikan 4 kesimpulan sebagai berikut:

Pada tingkat sekolah dasar di Kota Pekalongan pendidikan Agama Khonghucu telah dilaksanakan di dua sekolah dasar yaitu SDN Sampangan 02 dan SD Satyawiguna Kota Pekalongan. Namun, dari jumlah jam pelajaran terdapat perbedaan antara kedua sekolah tersebut. Jumlah jam pelajaran pendidikan agama secara umum dan Khonghucu secara khusus pada SDN Sampangan 02 dilaksanakan sesuai dengan Permendiknas No 22 tahun 2006 yaitu 3 jam pelajaran. Sedangkan SD Satyawiguna melakukan modifikasi menjadi 2 jam pelajaran, hal tersebut tentu saja tidak sesuai dengan Permendiknas No 22 tahun 2006.

Kompetensi guru pendidikan Agama Khonghucu pada tingkat sekolah dasar dibagi menjadi dua yaitu berdasarkan kualifikasi akademik dan standar kompetensi guru. Berdasarkan kualifikasi akademik, guru pendidikan Agama Khonghucu pada tingkat sekolah dasar belum memiliki kualifikasi akademik sarjana ataupun kualifikasi yang diperoleh dari uji kesetaraan oleh universitas yang terkait. Dengan kata lain secara kualifikasi akademik guru pendidikan Agama Khonghucu pada tingkat sekolah dasar belum sesuai dengan apa yang persyaratkan dalam Permendiknas No 16 tahun 2007 tentang kompetensi akademik guru.

Berdasarkan standar kompetensi yang dinilai dari paedagogik, profesionalitas, kepribadian dan sosial berdasarkan penilaian pimpinan, teman sejawat dan penilaian pribadi maka dapat disimpulkan rerata standar kompetensi guru pendidikan agama Khonghucu berada dalam standandar minimal (baik). Standar minimal ini perlu ditingkatkan agar menjadi sangat baik sesuai dengan standar kompetensi maksimal.

Kurikulum pendidikan Agama Khonghucu yang dilaksanakan pada sekolah tingkat dasar di Pekalongan menggunakan kurikulum yang disusun oleh Majelis Tinggi Agama Khonghucu Indonesia. Kurikulum ini berbeda dengan yang disusun berdasarkan Permendiknas No 47 tahun 2008 tentang KTSP. 
Ada enam faktor penghambat dalam pelaksanaan pendidikan agama Khonghucu. Keenam faktor penghambat tersebut adalah sebagai berikut: Pertama, kualifikasi guru pendidikan agama Khonghucu. Kedua, perangkat pembelajaran seperti Sialabus dan RPP yang belum disusun oleh guru agama. Ketiga, proses pembalajaran yang monoton tanpa inovasi metode pengajaran. Keempat, ketidakmampuan guru pendidikan Agama Khonghucu untuk bergaul dan sharing pendapat dengan pimpinan dan teman sejawat. Kelima monitoring pimpinan sekolah dan Makin yang belum maksimal. Dan keenam, serta ketiadaan literatur atau referensi bagi siswa.

\section{UCAPAN TERIMA KASIH}

Pada akhir tulisan ini, penulis ingin mengucapkan terimakasih kepada Kepada Kepala SD Negeri 02 Sampangan dan SD Satyawiguna Pekalongan, Jiasong On Giok lan, Yuli Susanti, Suwito Widjojo (Oey Tjoe Gwie), Ketua Makin Kota Pekalongan, dan Js. Indang Wijaya, ketua Bidang Kerohanian Makin Pekalongan, serta Kementerian Agama Kota Pekalongan, dan masih banyak yang tidak bisa saya ucapkan satu persatu dalam tulisan ini. Pihak-pihak tersebut telah turut membantu terselesaikannya tulisan ini.

\section{DAFTAR PUSTAKA}

Brannen, Julia. 1992. Mixing Methods: Qualitative and Quantitative Research. Brookfield USA: Avebury.

Badan Standar Nasional Pendidikan. 2007. Standar Proses untuk satuan Pendidikan dasar dan Menengah.
Bloom, Benjamin S. (ed). 1974. Taxonomy of Educational Objectives The Classification of Educational Goals. Handbook I: Cognitive Domain New York, David McKay company

Daradjat, Zakiah, et.all. 2011. Ilmu Pendidikan Islam. Jakarta: Bumi Aksara.

Hadikusuma, Hilman. 1993. Antropologi Agama, Pendekatan Budaya Terhadap Aliran Kepercayaan, Agama Hindu, Budha, Khonghucu di Indonesia, Bagian I. Bandung: Citra Aditya Bakti.

Hurloch, Elizabeth B. 1993. Child Development, terj. Med. Meitasari Tjandrasa. Jakarta: Erlangga.

Instruksi Presiden No. 14 tahun 1967, tentang Agama Kepercayaan Dan Adat Istiadat Cina.

Keppres No. 6 tahun 2000 yaitu tentang pencabutan Inpres No. 14 tahun 1967.

Peraturan Pemerintah (PP) Nomor 55 Tahun 2007 tentang Pendidikan Agama dan Pendidikan Keagamaan.

Permendiknas No. 16 Tahun 2007 Tentang Standar Kompetensi Pendidik

Permendiknas No.41 Tahun 2007 Tentang Standar Proses.

Rachmadani, Arnis. 2009. Pembinaan Kehidupan Beragama Pada Masyarakat Tionghoa Yang Beragama Khonghucu di Kota Malang Jawa Timur. Semarang: Balai Litbang Agama.

Surat Edaran (SE) Menteri Dalam Negeri No. 477/74054/BA.012/4683/95 Tanggal 18 November 1978.

Sugiyono. 2008. Metode Penelitian Kulaitatif dan Kuantitatif ReD. Bandung: Alfabeta. 